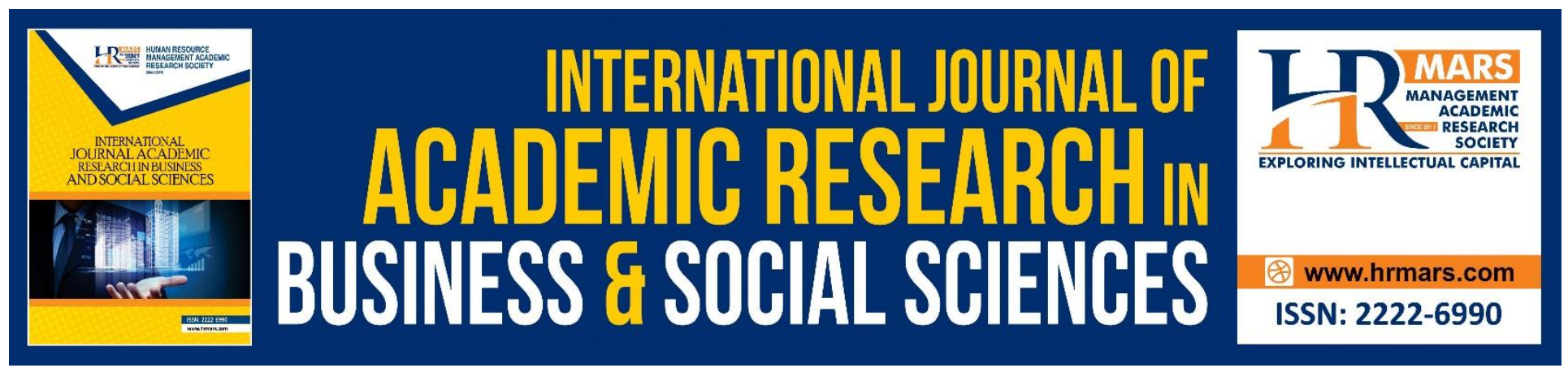

\title{
Relationship between Work Environment and Organizational Commitment among Private School Teachers in Klang Valley
}

$\mathrm{Ng}$ Pek Cheng and Suhaida Abdul Kadir

To Link this Article: http://dx.doi.org/10.6007/IJARBSS/v8-i7/4419

DOI: $\quad 10.6007 /$ IJARBSS/v8-i7/4419

Received: 06 June 2018, Revised: 23 June 2018, Accepted: 30 June 2018

Published Online: 23 July 2018

In-Text Citation: (Cheng \& Kadir, 2018)

To Cite this Article: Cheng, N. P., \& Kadir, S. A. (2018). Relationship between Work Environment and Organizational Commitment among Private School Teachers in Klang Valley. International Journal of Academic Research in Business and Social Sciences, 8(7), 781-793.

\section{Copyright: (C) 2018 The Author(s)}

Published by Human Resource Management Academic Research Society (www.hrmars.com)

This article is published under the Creative Commons Attribution (CC BY 4.0) license. Anyone may reproduce, distribute, translate and create derivative works of this article (for both commercial and non-commercial purposes), subject to full attribution to the original publication and authors. The full terms of this license may be seen

at: http://creativecommons.org/licences/by/4.0/legalcode

Vol. 8, No. 7, July 2018, Pg. 781 - 793

http://hrmars.com/index.php/pages/detail/IJARBSS

JOURNAL HOMEPAGE

Full Terms \& Conditions of access and use can be found at http://hrmars.com/index.php/pages/detail/publication-ethics 


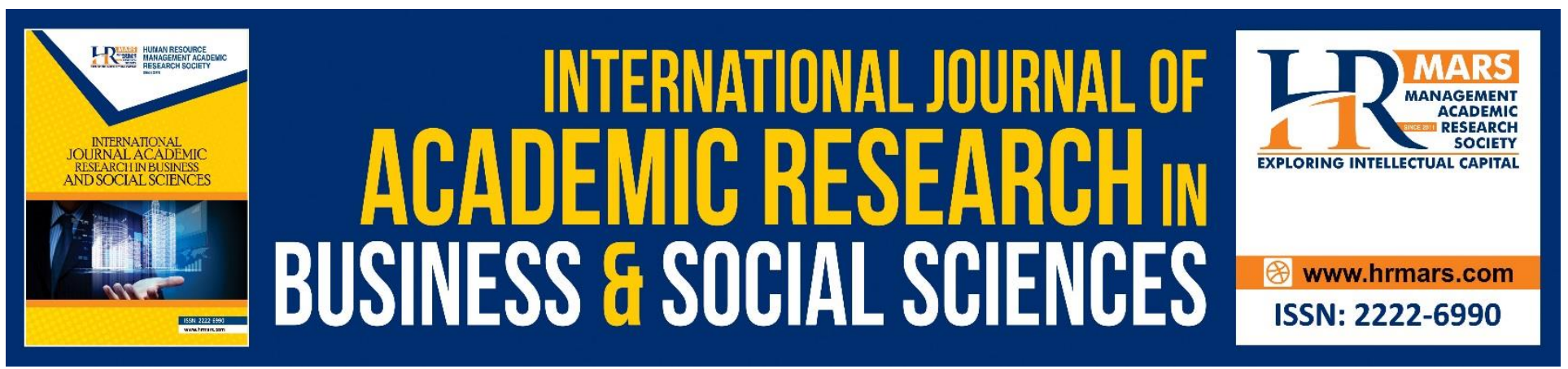

\title{
Relationship between Work Environment and Organizational Commitment among Private School Teachers in Klang Valley
}

\author{
$\mathrm{Ng}$ Pek Cheng and Suhaida Abdul Kadir
}

Faculty of Educational Studies, Universiti Putra Malaysia, 43400 UPM Serdang, Selangor, Malaysia

\begin{abstract}
The main purpose of this study is to determine the relationship between work environment and organizational commitment among private school teachers in Klang Valley. Survey questionnaires were distributed to five private schools. 110 private school teachers participated in the survey. Data regarding organizational commitment and work environment were analyzed by using IBM SPSS Software version 22.0. Descriptive statistic was employed to identify level of teachers' work environment and organizational commitment. Pearson correlation was used to analyze the relationship between work environment and organizational commitment among private school teachers. T-test is to identify the difference of private school teachers' organizational commitment based on gender. The results demonstrated that there are moderate relationships between teachers' work environment and teacher's organizational commitment. The findings also revealed that there are no significant different between female and male private school teachers in organizational commitment.
\end{abstract}

Keywords: Organizational Commitment, Private School Teachers

\section{Introduction}

In Malaysia Education Blueprint 2013-2015, Prime Minister Dato' Sri Haji Mohammad Najib bin Tun Haji Abdul Razak stated that education plays an important role in the development of social and economic capital in the country. He also stated the main component of the success in the country is the creativity, innovation and the skills from our nation. This statement shows that education is essential for every individual in the country. Since 2012, the development of private school have been increasing rapidly and more local students enrolled in private school (Keeling, A., 2015). Private school teachers have more options to teach in different school. Teachers who are being offered with higher wages often move to other schools.

Good teachers are in short supply in private school (Lee, 2013). Private school have high turnover rates, especially small size of private school (Ingersoll, 2001). Reason of teacher turnover is disagreement with school policy, teachers and inconsistent opinion (Ingersoll, 2011). In future, the 
INTERNATIONAL JOURNAL OF ACADEMIC RESEARCH IN BUSINESS AND SOCIAL SCIENCES Vol. 8, No. 7, July 2018, E-ISSN: 2222-6990 @ 2018 HRMARS

number of private school will increase in Malaysia. The issues of teacher's turnover in private school will continue if sector of private education institution are not aware of teachers' organizational commitment.

Teachers' organizational commitment is an essential aspect in achieving school's success because highly committed teachers will devote more of their time and put extra effort in their work to attain school's goals. When teacher are committed, school will be more effective and productive (Cammellia Othman \& Jati Kasuma, 2016). A long term success of a school depends on the commitment of the teachers. Therefore, organizational commitment is an important issue to run a school. Improving the level of organization commitment of an individual can reduce the turnover intention in an organization (Lew, 2011). Furthermore, many research towards organizational commitment showed that the most significant result of organization is by maintaining a high degree of organizational commitment.

Research showed that teacher with organizational commitment are perceived as having high belongingness and identification with the school (Mclnerney et al, 2015). As school appreciates teacher's contribution and concern about their well being are more likely to maintain and enhance teachers' commitment. Apart from that, a conducive working environment is able to enhance organizational commitment (Hanaysha, 2016). Good affiliation among teachers has a significant positive effect on organizational commitment (Hanaysha, 2016). Thus, work environment is an important factor that can affect commitment among employee.

\section{Literature Review}

\section{Organizational Commitment}

Allen \& Meyer (1996) defined organizational commitment is a emotional bonding between employee and their organization which employee have personal attachment to the organization and stay with the organization. Organizational commitment affects whether an employee stays as a member of the organization or leaves to pursue another job (Colquitt et al., 2013). Allen and Meyer (1990) stated that organizational commitment have three component construct namely affective commitment, continuance commitment, and normative commitment. The affective commitment represents emotional bond to the organization and willing to exert extra effort on behalf of the organization. The continuance commitment represents a willingness to remain as a member of an organization because of perceived cost of leaving. The normative commitment develops as a result of socialization experiences and emphasizes the feeling of obligations to organization.

Affective commitment of an employee showed that they expend extra effort to their work when they had strong loyalty feeling toward their organization (Ekrot et al., 2016). Employees can perform better duty when they have affective commitment to the organization (Meyer and Allen, 1997). Emotional attachment of an employee reflects the emotional element in the employee and employer relationship which is affection, belongingness and support (Fernandez-Lores et al., 2015).

According to Meyer \& Allen (1984), the invested value to an employee is perceived as a lost when the employee leave the organization. The perceived cost of leaving can be worse when organization did not take action to replace a new employee. This situation explained a person commitment to an organization which named as continuance commitment. Continuance commitment can be increased when employment alternative is lesser (Colquitt et al., 2013), they cannot afford to leave with the 
INTERNATIONAL JOURNAL OF ACADEMIC RESEARCH IN BUSINESS AND SOCIAL SCIENCES

Vol. 8, No. 7, July 2018, E-ISSN: 2222-6990 @ 2018 HRMARS

effort, time with the organization and benefits, for instance, retirement fund. Therefore, employee need to stay with the organization (Allen \& Meyer 1990, Meyer \& Herscovitch 2001).

Normative commitment exists when there is a moral intuition and feeling of rightness (Colquitt et al., 2013). It emphasizes on the feeling of obligation from the employee to stay with the organization (Tolentino, 2013). The sense of obligation is developed in the organization culture and family (Meyer and Allen, 1997). Employees with strong normative commitment are loyal to a particular organization and they exhibit the feeling of ought to remain in the the organization (Tolentino, 2013).

Erdem \& Ucar (2013) examined the level of organizational commitment among primary school teachers. There are 429 teachers of teachers who worked in primary schools was participated in the study. Overall organization commitment levels of primary school teachers are moderate (Erdem \& Ucar, 2013). In Malaysia context, Siti Fairuz Hamid et al. (2013) examine the level of organizational commitment among the primary school teachers in the district of Klang. 258 daily primary school teachers in the district of Klang participated in the study. The findings revealed that most of the teachers perceived themselves as moderately committed to their schools (Siti Fairuz Hamid et al., 2013). It demonstrated level of organizational commitment among the primary school teachers in Klang is moderate. Nik Mustafa Mat Ail et al. (2015) conducted a survey using quantitative methods to examine the of teachers' commitment in three Mara Junior Science Colleges (MJSCS) in Pahang. The results found that the commitment level of the teachers in three MJSCs in Pahang is high. The teachers feel commited to their organization (Nik Mustafa Mat Ail et al., 2015).

Raman et al. (2015) has conducted a study to determine the relationship between school climate and teachers' commitment. The population of this study are teachers from five excellent schools in the district of Kubang Pasu, Kedah, Malaysia. The finding demonstrated that teachers' commitment in the five excellent schools were high (Raman et al., 2015). Ling (2012) had done a study on identifying level of teachers' commitment. This study is carried out at secondary schools in Miri, Sarawak. There are 1014 trained teachers participated in the study. The findings showed that teachers' commitment in twenty-seven secondary school were moderate (Ling, 2012).

Previous research explored the level of teachers' commitment in Malaysia secondary school (Teoh et al., 2017). 384 secondary school teachers across Malaysia were took part in the study. The results found that teacher commitment was high among Malaysian secondary school teachers. Teachers were very committed to their teaching profession and teaching work. In addition, findings showed that secondary school teachers in Malaysia are committed to school (Teoh et al., 2017).

\section{Work Environment}

Work environment is a main factor that influences employee's sense of well-being and commitment toward an organization (Hanaysha, 2016). Fisher \& Fraser (1990) proposed eight dimension of schoollevel environment, there are 1) student support; (2) affiliation; (3) professional interest; (4) staff freedom; (5) participatory decision making; (6) innovation; (7) resource adequacy; and (8) work pressure. Student support is described as the good rapport between teachers and students; student's behavior of responsible and self-disciplined manner. Affiliation is the relationship among teachers, teachers able to obtain assistance, advice and encouragement to made them feel closed with each other. In the dimension of professional interest, Fisher \& Fraser (1990) mentioned about teachers 
INTERNATIONAL JOURNAL OF ACADEMIC RESEARCH IN BUSINESS AND SOCIAL SCIENCES Vol. 8, No. 7, July 2018, E-ISSN: 2222-6990 @ 2018 HRMARS

discuss professional matter, show interest in their work and seek for further professional development. Staff Freedom described as the teachers are free of set rules, guidelines, procedures and supervision to ensure rule compliance. In participatory decision making, teachers have the opportunity to participate in decision making. Innovation is the school in favour of planned change and experimentation, and fosters classroom openness and individualisation. Resource adequacy describe as support personnel, facilities, finance, equipment and resources are suitable and adequate. The last dimension is work pressure, it described as the extent to which work pressure dominates the school environment (Fisher \& Fraser, 1990).

Previous research explored the relationship between the work environment and school quality (Allodi \& Fischbein, 2012). Result showed that female teacher have high pressured with their workload as compare to male teacher and young teacher have less decision making in school. The research further showed that there is positive link between teacher's work environment and the school quality.

Research demonstrated affiliation among teachers by helping each other, sharing ideas have significantly affect school environment (Aldridge \& Fraser, 2016). It also revealed that school-level environment have correlation to teacher's commitment. Teachers who perceive that they have the professional respect and admiration of their colleagues, in addition to acknowledge their expertise and knowledge, will be more inclined to contribute to their schools. Their contribution will be exhibited in the expression of greater commitment to the profession and the organization (Bogler and Somech, 2004).

\section{Relationship between Work Environment and Organizational Commitment}

In order to operate with greater potential in school, it is a necessary to make sure teachers are working in a comfortable and friendly environment. Working environment are encompasses working hour, job safety and security, relationship with colleagues, esteem needs and top administration in the school. Employee loyalty, level of commitment, efficiency \& effectiveness productivity, can be improve by working in good work environment. Besides it also promote a sense of ownership among employees which ultimately increases organizational effectiveness as well as reduces prohibit cost emerging as a result of dissatisfied employees (Raziqa \& Maulabakhsha, 2015). Employees will be more effectively and like working when they work in a conducive work environment (Khuong \& Le, 2014). Previous study show that school-level environment has the relationships with professional and organizational commitment (Tran \& Le, 2015).

Jo (2014) examined the associations between teachers' relationships and teacher commitment. This study focused on organizational commitment of teachers as it relates to teaching, students, and the general school environment. Given that the quality of teachers' relationships is subject to the circumstances of individual schools, the focus on organizational rather than professional commitment maintains congruence with proposed antecedent variables. The participant of this study is 448 teachers in primary and middle schools in South Korea. One of the scale items developed by Revised School Level Environment Questionnaire Relationships were measured with six identical indicators for each relationship with students, colleagues, principals, parents, and local educational authorities. Finding showed a significant and positive path association between collegial relationships and teacher commitment (Jo, 2014). This indicated that teachers in more favorable collegial relationships had greater teacher commitment. Favorable teacher and student relationships were 
INTERNATIONAL JOURNAL OF ACADEMIC RESEARCH IN BUSINESS AND SOCIAL SCIENCES Vol. 8, No. 7, July 2018, E-ISSN: 2222-6990 @ 2018 HRMARS

indirectly related with teacher commitment. This study also found a meaningful association between the quality of teacher and principal relationships and levels of teacher commitment, such that better relationships were associated with increased levels of commitment. The importance of favorable relationships provides that teacher commitment is the collective responsibility of people involved with schools. Teacher commitment should be considered as a joint product of people inside and outside schools rather than an obligation required for individual teachers. Local educational authorities may participate in the co-work unless they are trapped in the indifference of teachers.

School climate is school environment or school-level learning environment (Johnsons \& Steve, 2006). A study found that there is positive significant relationship between school climate and teachers' commitment (Raman et at, 2015). This demonstrated the higher the level of school climate will have higher level of teachers' commitment. Sharing knowledge and being helpful among teachers can improve the colleagial relationship, as a result, teachers are more united and commited to the organization (Raman et at, 2015). Previous research showed that there is a strong positive impact of teacher collegiality on teacher commitment to school (Madiha Shah, 2012). Teachers who perceive their relationships with their colleague are cooperative and collegial are more organizationally committed.

\section{Methodology}

Descriptive research design was employed to investigate the relationship between work environment and organizational commitment among private school teachers in Klang Valley. This study was conducted in private schools by using survey. Three-Component Model (TCM) Employee Commitment Survey Questionaire is the instrument to measure teacher's perception of organizational commitment. The three-component model (TCM) employee commitment survey questionaire was developed by Allen \& Meyer (1990). This questionnaire consists of three component of commitment. There are affective commitment, normative commitment and continuance commitment. Work environment is measured by school-level environment questionnare from Fisher \& Fraser (1990).

Survey questionnaires are distributed to five private schools teachers in Klang Valley. The data collected from the respondent was analyzed by IBM SPSS Software version 22.0. The descriptive analysis is to determine the level of organizational commitment and work environment among private school teachers in Klang Valley. Pearson correlation was used to analyze the relationship between work environment and organizational commitment among private school teachers. An independent-samples t-test was used to compare the organizational commitment for males and females.

According to Ary et al., (2010), a population is defined as a group of people. The population of the study were 192 private school teachers. Stratified random sampling is used to identify the number of sample size in each school. Stratified random sampling is a process which certain subgroup are chosen for the sample based on proportion as they exist in the population (Fraenkel et al., 2012). 129 of questionnaires were distributed. Only 110 questionnaires were collected. 
INTERNATIONAL JOURNAL OF ACADEMIC RESEARCH IN BUSINESS AND SOCIAL SCIENCES Vol. 8, No. 7, July 2018, E-ISSN: 2222-6990 (C) 2018 HRMARS

\section{Research Finding}

The were 110 teachers completed the questionnaire. The background of the respondents was being analyzed in the aspects of gender and age. The demographic information of the respondents in term of frequency and percentage is presented in Table 1.1.

According to Table 1.1, 75 female and 35 male respondents participated in the study (68.2\% female, $31.8 \%$ male). $40 \%$ of respondents are between 31 to 40 years. $37.3 \%$ of respondents is between age of $21-30.13 .5 \%$ of respondents are in the age group of $41-50$. Only $4.5 \%$ of respondents are in the age group of $51-60$ and the remaining $4.5 \%$ are in the age group of $61-70$.

Table 1.1: Frequency and Percentage of Respondents' Demographic Profile

\begin{tabular}{llll}
\hline Demographic factors & Categories & Frequency(f) & Percentages(\%) \\
\hline Gender & Female & 75 & 68.2 \\
& Male & 35 & 31.8 \\
& Total & 110 & 100 \\
Age & & & \\
& $21-30$ & 41 & 37.3 \\
& $31-40$ & 44 & 40.0 \\
& $41-50$ & 15 & 13.6 \\
$51-60$ & 5 & 4.5 \\
& $61-70$ & 5 & 4.5 \\
& Total & 110 & 100
\end{tabular}

There are three dimension of organizational commitment: 1) affective commitment, 2) continuance commitment and 3) normative commitment. Each dimension has 8 items. The overall mean of affective commitment is 3.2000 , continuance commitment is 3.1523 , and normative commitment is 3.0716. Table 1.2 shows the mean and standard deviation of each dimension of organizational commitment. Findings showed that overall teacher's level of organizational commitment is moderate.

Table 1.2: Mean and Standard Deviation of Organizational Commitment

\begin{tabular}{lll}
\hline Dimension & Mean of score & $\begin{array}{l}\text { Standard } \\
\text { deviation }\end{array}$ \\
\hline Affective commitment & 3.2000 & .62516 \\
Continuance commitment & 3.1523 & .44457 \\
Normative commitment & 3.0716 & .49524 \\
Overall & 3.1413 & .35839 \\
\hline
\end{tabular}

The overall mean of work environment is 3.29 and standard deviation is .390. The highest mean is in the dimension of affiliation which has 3.72, standard deviation is .725. Finding shows that the 
INTERNATIONAL JOURNAL OF ACADEMIC RESEARCH IN BUSINESS AND SOCIAL SCIENCES Vol. 8, No. 7, July 2018, E-ISSN: 2222-6990 @ 2018 HRMARS

relationship among teachers are good. Professional interest has the mean score of 3.61 and standard deviation is .553. Table below shows mean and standard deviation of organizational commitment.

Table 1.3: Mean and Standard Deviation of Work Environment

\begin{tabular}{lll}
\hline Dimension & Mean of score & Standard \\
\hline Affiliation & 3.72 & .725 \\
Professional Interest & 3.61 & .553 \\
Staff Freedom & 3.60 & .616 \\
Resource Adequacy & 3.34 & .781 \\
Innovation & 3.26 & .501 \\
Student Support & 3.25 & .501 \\
Work Pressure & 2.81 & .648 \\
Participatory Decision Making & 2.53 & .679 \\
Overall & 3.29 & .390 \\
\hline
\end{tabular}

An independent-samples t-test was conducted to compare the organizational commitment for males and females. There was no significant difference in organizational commitment for females $(M=3.12$, $\mathrm{SD}=.365)$ and males $(\mathrm{M}=3.18, \mathrm{SD}=.346 ; \mathrm{t}(108)=-.839, \mathrm{p}=.403>.05)$. Hypothesis is failed to reject. The findings shows that there are no significant different between female and male private school teachers in organizational commitment. The magnitude of the differences in the means was very small (eta squared $=.01$ ).

Table 1.4: Independent T-Test of Organizational Commitment Based on Gender

\begin{tabular}{lllllll}
\hline Gender & $\begin{array}{l}\text { Number } \\
\text { teachers }\end{array}$ & Mean & SD & t-values & $\boldsymbol{d f}$ & Sig. \\
\hline Female & 75 & 3.12 & .365 & -.839 & 108 & .865 \\
Male & 35 & 3.18 & .346 & & & \\
\hline
\end{tabular}

A Pearson product-moment correlation coefficient was computed to assess the relationship between work environement and organizational commitment. There was a moderate positive correlation between the two variables $(r=.450 ; n=110 ; p=.000<0.5)$. Overall, there was a moderate positive significant relationship between the work environment and organizational commitment. This suggests that the strength of the correlation is moderate. Increases work environment in organization were correlated with increases in teacher's commitment. 
INTERNATIONAL JOURNAL OF ACADEMIC RESEARCH IN BUSINESS AND SOCIAL SCIENCES Vol. 8, No. 7, July 2018, E-ISSN: 2222-6990 @ 2018 HRMARS

Table 1.5: Pearson Correlation for Work Environment Mean with Organizational Commitment Mean

\begin{tabular}{lll}
\hline Variables & \multicolumn{2}{l}{ Organizational } \\
correlation value $(\mathbf{r})$ & .000 \\
\hline Work environment & $.450^{* *}$ & .000 \\
Resource Adequacy & $.472^{* *}$ & .000 \\
Innovation & $.394^{* *}$ & .000 \\
Staff Freedom & $.375^{* *}$ & .002 \\
Affiliation & $.298^{* *}$ & .013 \\
Student Support & $.237^{*}$ & .017 \\
Work Pressure & $.227^{*}$ & .040 \\
Professional Interest & $.196^{*}$ & .787 \\
Participatory Decision Making & .026 &
\end{tabular}

\section{Discussion}

From the descriptive analysis, it was revealed that teacher's perception on affective commitment, continuance and normative commitment were in moderate level. Overall, organizational commitment were found to be at moderate level. Findings are similar with the study by Erdem \& Ucar, (2013) which showed that overall organization commitment levels of primary school teachers are moderate. In addition, the findings is also coincide with Siti Fairuz Hamid et al., (2013) who revealed that most teachers perceived themselves as moderately committed to their schools. Poursoltani and Iraji (2011) in the study of Physical Education Teachers in Mashhad demonstrated that there is no significant difference between teacher's commitment based on gender. Previous studies showed that there is a significance difference of affective commitment by gender (Korso, 2013). Affective professional commitment in male teachers is higher than female teachers (Korso, 2013).

Teacher's perception on Affiliation, Professional Interest, Staff Freedom, Resource Adequacy, Innovation, Student Support and Work Pressure were in moderate level from the result. The highest perception level among all the dimension of work environmnt is affiliation. Result demonstrated that there are good collegiality among teachers. This findings is consistent with Madiha Shah (2012) stated that study showed good relationship among teachers. Teachers can help and rely on each other in the school. Furthermore, they can share their view and opinions about their personal life and school activities. Consequently, this encourage teachers to establish a true friendship.

According to the findings, teacher perceived higher level of work environment when students are helpful, well-behaved, well-mannered, cooperative and respect to the teachers. Teacher's responsibilities toward school as the relationship with students improve (Choi and Tang, 2009). Results showed that professional matters are discussed among teachers. Social interactions within the organization can enhance personal developement (Ostroff, 1993). Teachers can learn from each other about teaching and learning strategies in school. Moreover, teachers agreed that they are free to control and maintain in the classroom. Jackson (2009) stated teachers have more freedom to incorporate their teaching in the classroom are keen on teaching. 
The result of the analysis indicated that the teachers perceived moderate level of innovative in the organization. This result coincides with finding by Gunduz \& Balyer (2014), teacher consider school need moderate level of innovation. School management should renew their systems with the updated developements (Gunduz \& Balyer, 2014). Based of the findings from teacher's opinion, resource adequacy in school are at moderate level. Resource adequacy are important to carry out a complete teaching and learning. Furthermore, when teacher have a lot of workload they have higher work pressure (Suhaiel Amdan et al., 2016). Thus, teachers will not happy with the organization. Work pressure is also one of the important dimension to create a harmony work environment.

The lowest perception level among all the dimension of work environmnt is participatory decision making. School political issues, insufficient time and lack of harmony between teachers and administrators caused a limitations to teachers' decision making in the schools (Yao, 2014). Overall the level of work environment among private school teachers are moderate. This finding is in concordance with the result by Malinen and Savolainen (2016) which found that teacher perceived moderate level of work environment in school.

The strength of the correlation between work environment and organizational commitment is moderate. The result finding which proved that there is relationship between school climate and teachers' commitment is similar to the study by Raman et at, (2015) found that there is positive significant relationship between school climate and teachers' commitment. Teachers who perceive that being respect and admire by their colleagues will exhibit in higher commitment to the organization (Bogler and Somech, 2004). Employee who are more participative, prone to be positively related to commitment (Ostroff, 1993). Consequently, findings are supported by Madiha Shah, (2012) showed that there is a strong positive impact of teacher collegiality on teacher commitment to school.

Furthermore, teachers have more organizational commitment when they are free to have different teaching style in the classroom (Jackson, 2009). Additionally, when teachers perceive have more chances for professional growth, the tends to be more committed to their organization and the profession (Bogler and Somech, 2004). Moreover, teacher are more committed when they have higher opportunity in decision-making (Bogler and Somech, 2004). Overall, teacher's work environment is an important element to determine teacher's commitment in school (Suhaiel Amdan et al., 2016).

Commitment is one of the important issues concerned by management of the organization. According to Colquitt et al. (2013), employee tends to leave the organization when their emotional attachment became lesser. It is considered a lost to the organization whenever employee leave the organization (Meyer \& Allen, 1984). Employer or management are responsible to consider the necessity and needs of different teacher's gender in school. Policies makers can improve the policies related to teacher's commitment. Teacher is the main resources in the school. It is crucial to retain teachers to operate a school. Teachers' commitment plays an important role to build a successful private school. 
INTERNATIONAL JOURNAL OF ACADEMIC RESEARCH IN BUSINESS AND SOCIAL SCIENCES

Vol. 8, No. 7, July 2018, E-ISSN: 2222-6990 @ 2018 HRMARS

\section{References}

Aldridge, J.M., \& Fraser, B.J. (2016). Teachers' views of their school climate and its relationship with teacher self-efficacy and job satisfaction. Learning Environment Research, 19, 291-307.

Allen, N. and Meyer, J. (1990). The measurement and antecedents of affective, continuance, and normative commitment to the organization. The Journal of Occupational Psychology, 63, 1-18.

Allen, N.J., \& Meyer, J.P. (1996). Affective, Continuance, and Normative Commitment to the Organization: An Examination of Construct Validity. Journal of Vocational Behavior, 49(43), 252276.

Allodi, M. W., \& Fischbein, S. (2012). Teachers' Perceptions of their Work Environment in Swedish Junior High Schools. Research in Comparative and International Education, 7(3), 376-393.

Ary, D., Jacobs, L.C., Sorensen, C. and Razavieh, A. (2010). Introduction to Research in Education. Canada: Wadsworth, Cengage Learning.

Bogler, R., \& Somech, A. (2004). Influence of teacher empowerment on teachers' organizational commitment, professional commitment and organizational citizenship behavior in schools. Teaching and Teacher Education, 20, 277-289

Cammellia Othman \& Jati Kasuma (2016). Relationship of School Climate Dimensions and Teachers' Commitment. Journal of Contemporary Issues and Thought, 6, 19-29.

Choi, P.L. and Tang, S.Y.F. (2009). Teacher commitment trends: Cases of Hong Kong teachers from 1997 to 2007. Teaching and Teacher Education, 25:767-777

Colquitt, J.A., Lepine, J.A., Wesson, M.J. (2013). Organizational behaviour: Improving performance and commitment in the workplace. New York: McGraw-Hill

Ekrot, B., Johannes, R. J., \& Gemünden, H.G. (2016). Antecedents of project managers' voice behavior: The moderating effect of organization-based self-esteem and affective organizational commitment. International Journal of Project Management, 34, 1028-1042.

Erdem, M. \& Ucar, I.H.(2013). Learning Organization Perceptions in Elementary Education in terms of Teachers and the Effect of Learning Organization on Organizational Commitment. Educational Sciences: Theory \& Practice, 13(3), 1527-1534.

Fernandez-Lores, S., Gavilan, D., Avello, M. \& Blasco, F. (2015). Affective commitment to the employer brand: Development and validation of a scale. Business Research Quarterly, 19, 40-54.

Fisher, D. L., \& Fraser, B. J. (1990). Validity and use of the School-Level Environment Questionnaire. Paper presented at the annual meeting of the American Educational Research Association, Boston, MA.

Fraenkel, J. R., Wallen, N. E., \& Hyun, H.H. (2012). How to design and evaluate research in education. New York: McGraw-Hill.

Gunduz, Y. \& Balyer, A. (2014). Examining Innovation Needs of Primary Schools: Teachers' Perceptions. Procedia-Social and Behavioral Sciences, 116, 139-143.

Hanaysha, J. (2016). Testing the Effects of Employee Engagement, Work Environment, and Organizational Learning on Organizational Commitment. Procedia - Social and Behavioral Sciences, 229, 289-297.

Ingersoll, R. (2001). Teacher turnover and teacher shortages: an organizational analysis. American Educational Research Journal, 38, 499-534.

Lee, J. (2013, October 11). Education's evolution. The Star. Retrieved from https://www.thestar.com.my/business/sme/2013/10/11/educations-evolution-the-landscapeof-learning-in-malaysia-is-changing-rapidly/ 
INTERNATIONAL JOURNAL OF ACADEMIC RESEARCH IN BUSINESS AND SOCIAL SCIENCES

Vol. 8, No. 7, July 2018, E-ISSN: 2222-6990 @ 2018 HRMARS

Mclnerney, D.M., Ganotice, F.A., King, R.B., Marsh, H.W., \& Mortin, A.J.S. (2015). Exploring commitment and turnover intentions among teachers: What we can learn from Hong Kong teachers. Teaching and Teacher Education, 52, 11-23.

Meyer, J.P., \& Allen, N.J. (1997). Commitment in the Workplace: Theory, Research and Application. Thousand Oak, CA: Sage.

Meyer, J.P., \& Allen, N.J. (1984). Testing the "side-bet theory" of organizational commitment: some methodological considerations. Journal of Applied Psychology, 69(3), 372-378.

Meyer, J.P., \& Herscovitch, L. (2001). Commitment in the workplace; toward a general model. Human Resource Management Review, 11, 299-326.

Ministry of Education Malaysia (2012). Malaysia Education Blueprint 2013-2025. Putrajaya: Ministry of Education Malaysia.

Jackson, T.O. (2009). Towards collective work and responsibility: Sources of support within a Freedom School teacher community. Teaching and Teacher Education, 25, 1141-1149.

Johnson, B., \& Stevens, J.J. (2006). Student achievement and elementary teachers' perceptions of school climate. Learning Environments Research, 9(2), 111-122.

Jo, S.H. (2014). Teacher commitment: Exploring associations with relationships and emotions. Teaching and Teacher Education, 43, 120-130.http://dx.doi.org/10.1016/j.tate.2014.07.004

Keeling, A. (2015, March 26). Expert Analysis: Increasing Number of International School Students in Malaysia are Local Children Aiming High. Retrieved from http://www.privateinternationalschoolfair.com/news/expert-analysis-increasing-number-ofinternational-school-students-in-malaysia-are-local

Khuong, M. N., \& Le Vu, P. (2014). Measuring the effects of drivers organizational commitment through the mediation of job satisfaction: A Study in Ho Chi Minh City, Vietnam. International Journal of Current Research and Academic Review, 2(2), 1-16.

Korso, G. B. (2013). Teachers' Perceived Commitment as Measured by Age, Gender and School Type. Greener Journal of Educational Research, 3(8), 363-372.

Lew, T.K. (2011). Affective Organizational Commitment and Turnover Intention of academics in Malaysia. International Conference on Business and Economics Research, 1, 111-114.

Ling, S. (2012). The Influence of Transformational Leadership on Teacher Commitment towards Organization, Teaching Profession, and Student Learning in Secondary Schools in Miri, Sarawak, Malaysia. International Journal for Educational Studies, 4(2), 155-178.

Madiha Shah. (2012). The Impact of Teachers' Collegiality on their Organizational Commitment in High and Low Achieving Secondary Schools in Islamabad, Pakistan. Journal of Studies in Education, 2(2), 130-156.

Malinen, O.P., \& Savolainen, H. (2016). The effect of perceived school climate and teacher efficacy in behavior management on job satisfaction and burnout: A longitudinal study. Teaching and Teacher Education, 60, 144-152.

Nik Mustafa Mat Ail, Mohd Radzi Taib, Hazlina Jaafar, Wan Aida Rohana Mohamed Salleh \& Mohd Nawawi Omar. (2015). Principals' Instructional Leadership and Teachers' Commitment in Three Mara Junior Science Colleges (Mjsc) In Pahang, Malaysia. Procedia -Social and Behavioral Sciences, 191, $1848-1853$.

Ostroff, C. (1993). The effects of climate and personal influences on individual behavior and attitudes in organizations. Organizational Behavior and Human Decision Processes, 56, 56-90. 
INTERNATIONAL JOURNAL OF ACADEMIC RESEARCH IN BUSINESS AND SOCIAL SCIENCES

Vol. 8, No. 7, July 2018, E-ISSN: 2222-6990 @ 2018 HRMARS

Poursoltani Z.R., \& Iraji N.R. (2011). The Study of Organizational Commitment Based on Personal Characteristics of Physical Education Teachers in Mashhad. Researcher in Sport Science Quarterly 2011, 2(3), 41- 49.

Raman, A., Chang, C.L., Rozalina Khalid. (2015). Relationship between School Climate and Teachers' Commitment in an Excellent School of Kubang Pasu District, Kedah, Malaysia. Mediterranean Journal of Social Sciences, 6(3), 163-173.

Raziqa, A. \& Maulabakhsha R. (2015). Impact of Working Environment on Job Satisfaction. Procedia Economics and Finance, 23, $717-725$.

Siti Fairuz Hamid, Norshidah Nordin, Afni Anida Adnan \& Norsiah Sirun. (2013). A study on primary school teachers' organizational commitment and psychological empowerment in the district of klang. Procedia - Social and Behavioral Sciences, 90, 782 - 787.

Suhaiel Amdan, Ramlee Abdul Rahman, Siti Asiah Md. Shahid, Saridan Abu Bakar, Masrur Mohd Khir \& Nur Atiqah Rochin Demong. (2016). The Role of Extrinsic Motivation on the Relationship between Office Environment and Organisational Commitment. Procedia Economics and Finance, $37,164-169$.

Teoh, H.K., Kannan, S., \& Chua, Y.P, (2017). The Effect of School Bureaucracy on the Relationship between Principals' Leadership Practices and Teacher Commitment in Malaysia Secondary Schools. Malaysian Online Journal of Educational Sciences, 5(1), 37-55.

Tolentino, R.C. (2013). Organizational Commitment and Job Performance of the Academic and Administrative Personnel. International Journal of Information Technology and Business Management, 15(1), 51-59.

Tran, V. D., \& Le, M.T.L. (2015). School Environment Factors as Predictors for Teachers' Teaching Efficacy, Teacher Stress and Job Satisfaction. International Education Research, 3(2), 28-46. doi:10.12735/ier.v3i2p28

Yao, J.L. (2014). Teacher Involvement in School Decision Making. Journal of Studies in Education, 4(3), 50-58. 